\title{
Characteristics of Digital Mass Media Officer in Media Convergent Age
}

\author{
Chantana Papattha, Prachyanun Nilsook, and Namon Jeerungsuwan
}

\begin{abstract}
The objectives of the research study were to: (1) study experts' perspective about mass media officers' characteristic in media convergent age and (2) synthesize characteristic of mass media officers toward individual competences. The qualitative research was to conduct in-depth interview from 21 experts who were the leader in the field of media. The experts were the executive in mass communication organizations and administrator in universities. The research results revealed that there were $\mathbf{1 4}$ elements of digital mass media officers' characteristic including interdisciplinary knowledge, keenness, communication skills, systematic thinking, creative thinking, analysis thinking, critical thinking, media literacy, flexibility in working, active learning and self-learning, mass communication ethics, public consciousness and responsibility, multi-skilling, and integration and application to work. The syntheses characteristic toward individual competences of mass media officer consisted of three elements included knowledge, skills, and attributes. The knowledge elements composted of three essential elements including interdisciplinary knowledge, media literacy, and mass communication ethics. The skill elements consisted of eight essential elements including communication skills, systematic thinking, creative thinking, analysis thinking, critical thinking, active learning and self-learning, and multi-skilling. The attribute elements comprise of four essential included keenness, flexibility in working, public consciousness and responsibility, and integration and application to work.
\end{abstract}

Index Terms-Characteristic, digital mass media officer, individual competences, media convergent age.

\section{INTRODUCTION}

At present, the globalization faced an urgent problem on the increase of the population, the demand factors of life, progress of science and technology, and the change of the way of life. It is essential for human to adapt themselves with the technological change [1]. Quality education management was essential for the growth of every nation due to the reason that education provides foundation for the growth in social, economic, political and technology sectors [2]. Considering Thailand revolutionized the country's educational system in 2011 and the better educational direction known as the $21^{\text {st }}$ Century skill that focused on individual skillset of the students [3]. The Thai National Education Act B.E. 2542 (A.C.1999) and Amendments (Second National Education Act B.E.

Manuscript received May 16, 2015; revised July 26, 2015.

Chantana Papattha and Prachyanun Nilsook are with the Division of Information and Communication Technology for Education, Faculty of Technical, King Mongkut's University of Technology North Bangkok (KMUTNB), Thailand (e-mail: chantana.p@rmutp.ac.th).

Namon Jeerungsuwan is with the Department of Technological Education, Faculty of Technical Education, King Mongkut's University of Technology North Bangkok, Thailand.
(2002) imposed an education reform stressing the curriculum development and modification of teaching methods to develop a students' critical idea, solution skills, and the awareness of the value of culture [4]. Quality of life has been improved through better access to various economic and social security measures and gains in poverty reduction. It is, however, essential to place emphasis on the development of human capital and security, promotion of good governance and fair competition, and a more equitable distribution of development benefits in order to reduce social inequality [5].

Office of the Higher Education Commission (HEC) [5] acts as a regulatory agency to promote the operation of higher education institutions Thai Qualifications Framework for Higher Education: TQF for HEd. The TQF for HEd was the measurement to drive the policy in the National Education Act B.E. 2542 (1999) and Amendments [Second National Education Act B.E. (2002)]. The HEC had set the standard professional qualification and adopted the standard across the country. One responsibility of higher education institute was to provide education based on TQF for HEd, however in Thailand there was no designated National Qualification Framework for Higher Education degree in mass communication and communication arts. The education that aims to develop knowledge, thinking ability, and moral is a device to progress human [6]. Quality graduates must be knowledge, capacity, attitude, and multi-skills to develop the potential latency and the self-sufficiency of the graduates [6]. The study intended to find digital mass media officer's characteristics in experts' perspective to synthesize characteristic of mass media officer toward individual competences for design model of the education management in media convergent age.

\section{OBJECTIVES OF THE STUDY}

The objectives of the research study were to study experts' perspective about mass media officers' characteristic in media convergent age and synthesize characteristic of mass media officer toward individual competences of mass media office for designing model of the education management in media convergent age.

\section{RESEARCH METHODS}

The methodology was the qualitative research. Two steps in the study:

Step 1: Study experts' perspective about of mass media officers' characteristic was to conduct in-depth interview from the 21 experts who were leadership in the field of media consisted of executive in mass communication 
organizations and administrator in universities in the field of communication arts and mass communication.

Step 2: analysis and synthesis data from in-depth interview to find characteristic of mass media officer in media convergent age. Synthesize characteristic of mass media officer based-on individual competences of digital mass media officer's characteristic to design model of the education management.

\section{RESUlts}

Result of the research study presented the following results:

Part 1 results: There were 14 elements of digital mass media officers' characteristic in media convergent age by 21 experts presented in Table I.

TABLE I: SYNTHESIS EXPERTS' PERSPECTIVE ABOUT OF DigitAL MASS MEdia OFFICERS' CHARACTERISTIC

\begin{tabular}{|c|c|c|c|c|c|c|c|c|c|c|c|c|c|c|c|c|c|c|c|c|c|c|}
\hline \multirow{2}{*}{ Experts' perspective } & \multicolumn{21}{|c|}{21 Experts } & \multirow{2}{*}{$\begin{array}{c}\text { digital mass media } \\
\text { officers' } \\
\text { characteristic }\end{array}$} \\
\hline & 1 & 2 & 3 & 4 & 5 & 6 & 7 & 8 & 9 & 10 & 11 & 12 & 13 & 14 & 15 & 16 & 17 & 18 & 19 & 20 & 21 & \\
\hline 1. Interdisciplinary knowledge & $x$ & $x$ & $x$ & $x$ & $x$ & $x$ & $x$ & $x$ & $x$ & $x$ & $x$ & $x$ & $x$ & $x$ & $x$ & $x$ & $x$ & $x$ & $\bar{x}$ & $x$ & $x$ & $\mathbf{x}$ \\
\hline 2. Keenness & $x$ & $x$ & & $x$ & $x$ & $x$ & $x$ & $x$ & $x$ & $x$ & $x$ & $x$ & $x$ & $x$ & $x$ & $x$ & $x$ & $x$ & $x$ & $x$ & $x$ & $x$ \\
\hline 3. Communication skills & $x$ & $x$ & $x$ & $x$ & $x$ & $x$ & $x$ & $x$ & $x$ & $x$ & $x$ & $x$ & $x$ & $x$ & $x$ & $x$ & $x$ & $x$ & $x$ & $x$ & $x$ & $x$ \\
\hline 4. Writing skill & $x$ & & $x$ & & & & & & & & & & & $x$ & $x$ & $x$ & & $x$ & $x$ & $x$ & $x$ & \\
\hline 5. System thinking & $x$ & & & $x$ & & & $x$ & $x$ & $x$ & & $x$ & $x$ & $x$ & & $x$ & $x$ & $x$ & $x$ & $x$ & & & $x$ \\
\hline 6. Creative thinking & $x$ & $x$ & $x$ & $x$ & $x$ & $x$ & $x$ & $x$ & $x$ & $x$ & $x$ & $x$ & $x$ & $x$ & $x$ & $x$ & $x$ & $x$ & $x$ & $x$ & $x$ & $x$ \\
\hline 7. Analysis thinking & & $x$ & & $x$ & $x$ & & $x$ & $x$ & & & & & & $x$ & $x$ & $x$ & $x$ & $x$ & & $x$ & & $x$ \\
\hline 8. Synthesis thinking & & $x$ & & & $x$ & & & $x$ & & & $x$ & & & $x$ & & $x$ & & $x$ & & & & \\
\hline 9. Critical thinking & & $x$ & & $x$ & $x$ & $x$ & $x$ & $x$ & $x$ & & $x$ & & $x$ & & & $x$ & $x$ & $x$ & $x$ & & & $x$ \\
\hline 10.Media literacy & $x$ & $x$ & $x$ & & $\bar{x}$ & $x$ & & $x$ & & $x$ & & & & $x$ & $x$ & & & $x$ & $x$ & & & $x$ \\
\hline 11.Flexibility in working & $x$ & $x$ & & & $x$ & $x$ & $x$ & $x$ & $x$ & $x$ & $x$ & $x$ & $x$ & $x$ & $x$ & $x$ & $x$ & $x$ & & $x$ & $x$ & $x$ \\
\hline 12.Active learning and learning person & $x$ & $x$ & $x$ & $x$ & $x$ & $x$ & $x$ & $x$ & $x$ & $x$ & $x$ & $x$ & $x$ & $x$ & $x$ & $x$ & $x$ & $x$ & $\bar{x}$ & $x$ & $x$ & $x$ \\
\hline 13.Mass communication ethic & $x$ & $x$ & $x$ & $x$ & $x$ & $x$ & $x$ & $x$ & $x$ & $x$ & $x$ & $x$ & $x$ & $x$ & $x$ & $x$ & $x$ & $x$ & $\bar{x}$ & $x$ & $x$ & $x$ \\
\hline $\begin{array}{l}\text { 14.Public consciousness and } \\
\text { responsibility }\end{array}$ & $x$ & $x$ & & & $\mathbf{x}$ & $x$ & $x$ & $x$ & $x$ & $x$ & $x$ & $x$ & $x$ & $x$ & $x$ & $x$ & $x$ & $x$ & $\mathbf{x}$ & & & $x$ \\
\hline 15.Multi-skills & $x$ & $\mathbf{x}$ & $x$ & $x$ & $x$ & $x$ & $x$ & $x$ & $x$ & $x$ & $\mathbf{x}$ & $\mathbf{x}$ & $x$ & $x$ & $\boldsymbol{x}$ & $x$ & $x$ & $x$ & $x$ & $\mathbf{x}$ & $x$ & $x$ \\
\hline $\begin{array}{l}\text { 16. Awareness and attitude to career in } \\
\text { mass communication }\end{array}$ & & & $x$ & & $x$ & $x$ & & $x$ & & & & & $x$ & & $x$ & $x$ & & $x$ & & & & \\
\hline 17.Integration and application to work & $x$ & $x$ & $x$ & $x$ & $x$ & $\mathbf{x}$ & $x$ & $x$ & $\mathbf{x}$ & $x$ & $x$ & $x$ & $x$ & $x$ & $x$ & $x$ & $x$ & $x$ & $x$ & $x$ & $x$ & $x$ \\
\hline
\end{tabular}

Table I showed synthesis experts' perspective about of digital mass media officers' characteristic in media convergent age consisted of 14 elements included interdisciplinary knowledge, keenness, communication skills, system thinking, creative thinking, analysis thinking, critical thinking, media literacy, flexibility in working, active learning and self-learning, mass communication ethics, public consciousness and responsibility, multi-skilling, and integration and application to work.

Part 2 result: there were synthesis characteristic of mass media officer toward individual competences for designing model of the education management in media convergent age presented in Table II.

TABLE II: SYNTHESIS CHARACTERISTIC OF MASS MEDIA OFFICER TOWARD INDIVIDUAL COMPETENCES FOR DESIGNING MODEL OF THE EDUCATION MANAGEMENT IN MEDia CONVERGENT AGE

\begin{tabular}{l|c|c|c}
\hline \hline \multirow{2}{*}{ Experts' perspective } & \multicolumn{2}{c}{ Individual Competences [7], [8] } \\
\cline { 2 - 4 } & Knowledge & \multicolumn{1}{c}{ Skills } & \multicolumn{1}{c}{ Attributes } \\
\hline 1. Interdisciplinary knowledge & $\mathbf{x}$ & & \\
\hline 2. Keenness & & & $\mathbf{x}$ \\
\hline 3. Communication skills & & $\mathbf{x}$ & \\
\hline 4. System thinking & & $\mathbf{x}$ & \\
\hline 5. Creative thinking & & $\mathbf{x}$ & \\
\hline 6. Analysis thinking & & $\mathbf{x}$ & \\
\hline 7. Critical thinking & & $\mathbf{x}$ & \\
\hline 8. Media literacy & $\mathbf{x}$ & & \\
\hline 9. Flexibility in working & & & $\mathbf{x}$ \\
\hline 10.Active learning and self-learning & & $\mathbf{x}$ & \\
\hline 11.Mass communication ethics & $\mathbf{x}$ & & \\
\hline $\begin{array}{c}\text { 12.Public consciousness and } \\
\text { responsibility }\end{array}$ & & & $\mathbf{x}$ \\
\hline $\begin{array}{l}\text { 13.Multi-skilling } \\
\text { 14.Integration and application to } \\
\text { work }\end{array}$ & & $\mathbf{x}$ & $\mathbf{x}$ \\
\hline \hline
\end{tabular}

Table II showed syntheses characteristic toward individual competences of mass media officer based-on individual competences framework [7], [8] consisted of three elements included knowledge, skills, and attributes. The knowledge elements composted of three essential included interdisciplinary knowledge, media literacy, and mass communication ethics. The skill elements consisted of eight essential included communication skills, system thinking, creative thinking, analysis thinking, critical thinking, active learning and self-learning, and multi-skilling. The attribute elements comprise of four essential included keenness, flexibility in working, public consciousness and 
responsibility, and integration and application to work. The individual competences of mass media officer in media convergent age presented mind map relation elements essential in Fig. 1.

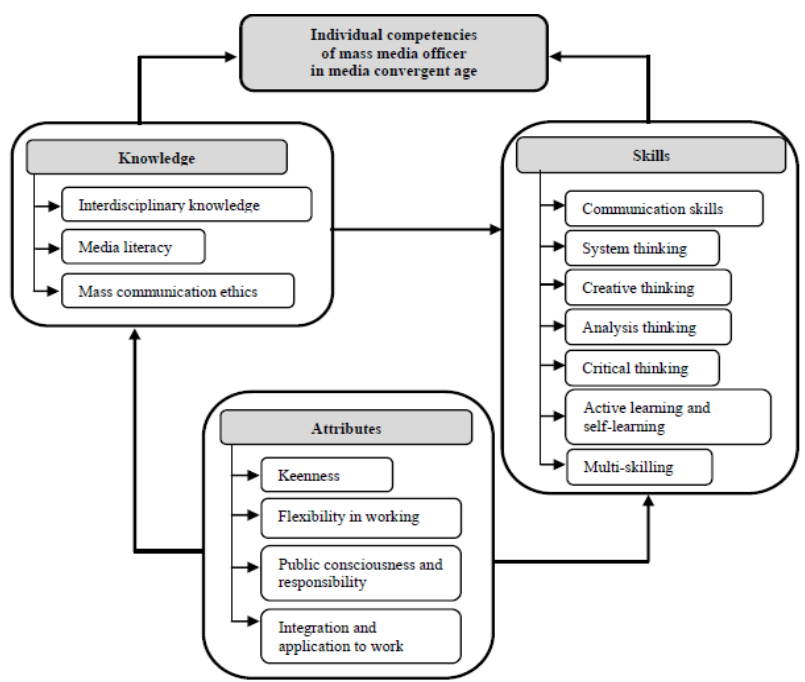

Fig. 1. Mind map relation elements essential of the individual competences of mass media officer in media convergent age based-on individual competences framework [7], [8]. Source: Designed by Chantana Papattha (2014).

\section{DISCUSSIONS}

The results of the study were 14 essential elements of digital mass media officers' characteristic in media convergent age included interdisciplinary knowledge, keenness, communication skills, system thinking, creative thinking, analysis thinking, critical thinking, media literacy, flexibility in working, active learning and self-learning, mass communication ethics, public consciousness and responsibility, multi-skilling, and integration and application to work. The 14 essential elements to synthesize the individual competences for designing the mass media education management consisted of three elements include knowledge, skills, and attributes. The results of the study with were consisted to the framework of Partnership for $21^{\text {st }}$ Century skills [3], [9] presented $21^{\text {st }}$ century student skills. Core subjects and $21^{\text {st }}$ century themes: Mastery of core subjects and 21 st century themes was essential to student success. Core subjects included English, reading or language arts, world languages, arts, mathematics, economics, science, geography, history, government and civics. In addition, schools must promote an understanding of academic content at much higher levels by weaving. Learning and Innovation Skills: Learning and innovation skills are what separate students who are prepared for increasingly complex life and work environments in today's world and those who are not. They include: Creativity and Innovation, Critical Thinking and Problem Solving, Communication and Collaboration, Information, Media and Technology Skills. Nowadays, we live in a technology and media-driven environment, marked by access to an abundance of information, rapid changes in technology tools and the ability to collaborate and make individual contributions on an unprecedented scale. Effective citizens and workers must be able to exhibit a range of functional and critical thinking skills, such as: Information
Literacy, Media Literacy, ICT (Information, Communications and Technology) Literacy, and Life and Career Skills. Today's life and work environments require far more than thinking skills and content knowledge. The ability to navigate the complex life and work environments in the globally competitive information age requires students to pay rigorous attention to developing adequate life and career skills, such as: Flexibility and Adaptability, Initiative and Self-Direction, Social and Cross-Cultural Skills, Productivity and Accountability, and Leadership and Responsibility. Finally, $21^{\text {st }}$ century support systems: Developing a comprehensive framework for 21 st century learning requires more than identifying specific skills, content knowledge, expertise and literacies. An innovative support system must be created to help students master the multi-dimensional abilities that will be required of them.

\section{CONCLUSION}

The research results revealed that experts' perspective consisted of 14 elements of digital mass media officers' characteristic which included interdisciplinary knowledge, keenness, communication skills, system thinking, creative thinking, analysis thinking, critical thinking, media literacy, flexibility in working, active learning and self-learning, mass communication ethics, public consciousness and responsibility, multi-skilling, and integration and application to work. The syntheses characteristic toward individual competences of mass media officer consisted of three elements included knowledge, skills, and attributes. The knowledge elements composted of three essential included interdisciplinary knowledge, media literacy, and mass communication ethics. The skill elements consisted of eight essential included communication skills, system thinking, creative thinking, analysis thinking, critical thinking, active learning and self-learning, and multi-skilling. The attribute elements comprise of four essential included keenness, flexibility in working, public consciousness and responsibility, and integration and application to work.

\section{ACKNOWLEDGMENT}

The authors were grateful for the financial support of the Faculty of Mass Communication Technology, Rajamangala University of Technology Phra Nakhon, Thailand. The authors also thanks for the supports of Vocational Education Technology Research Center and Innovation and Technology Research Center at Science and Technology Research Institute, and also Division of Information and Communication Technology for Education, Faculty of Technical Education, King Mongkut's University of Technology North Bangkok which supported the research study.

\section{REFERENCES}

[1] Thai Qualifications Framework for Higher Education 2009 and Regulation, Office of the Higher Education Commission, The Higher Education Commission, Bangkok, 2009, p. 1.

[2] Information and Communication Technology for Education Model Scheme of Ministry of Education, Ministry of education, Office of the Permanent Secretary, Ministry of Education, Bangkok, 2011, pp. 4-5. 
[3] Framework for $21^{\text {st }}$ Century Learning, Partnership for $21^{\text {st }}$ Century Skills, P21 Framework Definitions Publication, 2009, pp. 2-9.

[4] Thai Qualifications Framework for Higher Education 2009 and Regulation, The Higher Education Commission, Bangkok, 2009, pp. 19-20.

[5] Summary, The Eleventh National Economic and Social Development Plan (2012-2016.), Office of the National Economic and Social Development Board, Bangkok, 2011, p. 6.

[6] W. Chatakan, Management Techniques for Profession Education Administrator, Bangkok: Chulalongkorn University Press, 2012, p. 28

[7] O. Nordhaug, Human Capital in Organizations: Competence Training, and Learning, New York: Oxford University Press, 1993, p. 30.

[8] N. Wedchayanon, Competency-Based Approach. $6^{\text {th }}$ ed. Bangkok: The Graphic System, 2014, pp. 1-2.

[9] V. Panit, 21st Century Skills: The Way How Students Learn, Bangkok: Sodsri-Saridwongso Foundation, 2012, ch. 2.

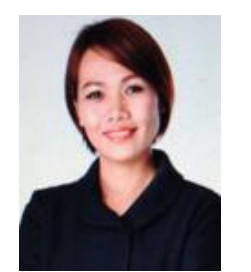

Chantana Papattha is studying the doctor of philosophy in information and communication technology for education at the Faculty of Technical Education, King Mongkut's University of Technology North Bangkok, Thailand. She obtained the bachelor's degree in computer education from Faculty of Education, Dhonburi Rajabhat Institute, Bangkok, Thailand in 2004; the bachelor's degree in multimedia journalism from Faculty of Mass Communication Technology, Ramkhamhaeng University, Bangkok, Thailand in 2013, and received the master's degree in technology computer from Faculty of Technical Education, King Mongkut's Institute of Technology North Bangkok, Bangkok, Thailand in 2007. She is currently a full time lecturer at the Department of Multimedia Technology, Faculty of Mass Communication Technology, Rajamangala University of Technology Phra Nakhon, Bangkok, Thailand. She is the associate editor of the International Journal of Learning in Higher Education, volume 19, issue 4, 2013 and the International Journal of Assessment and Evaluation, volume 20, issue 1, 2014.

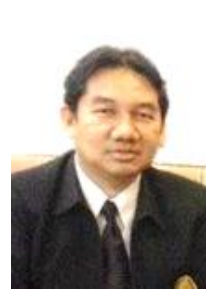

Prachyanun Nilsook is a Ph.D and he is an associate professor at Division of Information and Communication Technology for Education, Faculty of Technical Education, King Mongkut's University of Technology North Bangkok (KMUTNB), and Thailand. He received the B.Ed. degree in audio-visual education from Faculty of Education, Ramkhamhang University, Thailand in 1989. He obtained his M.Ed. degree in educational technology from Faculty of Education, Srinakarinwirot University, Thailand in 1995, and received the $\mathrm{Ph}$.D. degree in educational communications and technology from Faculty of Education, Chulalongkorn University in 2001 from 2001 to Present, he works in the field of information and communication technology in education. He has experience in many positions such as a dean, Faculty of Technical Education, Samutsongkhram Technical Collage, a dean, Faculty of Information and Communication Technology, Samutsongkhram Technical Collage, and the director of vocational education technology research center. He received national teachers award in higher education from National Teacher Council, Ministry of Education, and Thailand in 2004. He is a membership of professional societies in association for educational technology of Thailand (AETT).

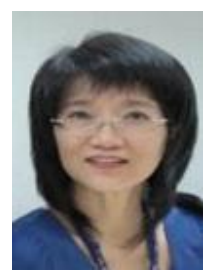

Namon Jeerungsuwan is a $\mathrm{Ph} . \mathrm{D}$ and she is currently a full time associate professor at the Department of Technological Education, Faculty of Technical Education, King Mongkut's University of Technology North Bangkok, Thailand. She has held a position of the director of Ph.D. program in information and communication technology for education since 2011. She was the head of the Department of Educational Technology, Kmutnb, during 2002-2006. She received her doctoral degree in instructional design and development from University of South Alabama and her master's degree in educational media from Western Oregon University. She also received the award of the Royal Thai Government Scholarship and the award of Kappa Delta Phi during she was pursuing the doctoral degree in the USA. Her past experience included Director of Online Learning Center, KMUTNB. Currently, she is the executive committee of the e-Learning Association of Thailand, the Educational Technology Association of Thailand, and the associate editor of International Journal of Technology, Knowledge, and Society, and the member of IEEE society. 